\title{
Influence of Fertilization System on the Quality of Cucumbers
}

\author{
Gheorghe CIMPEANU'*, Gabriela NEATA', Razvan TEODORESCU', \\ Carmen CIMMPEANU' ${ }^{1}$, Ionel FOLEA ${ }^{2}$ \\ ${ }^{1}$ University of Agronomical Sciences and Veterinary Medicine Bucharest, Faculty of Horticulture, \\ Marasti, 59,Dist.1, Bucharest,Romania; campeanu0136@yahoo.com \\ ${ }^{2}$ University of Biotera, Bul. Ion Ionescu de la Brad, 121, Dist.1, Bucharest, Romania
}

\begin{abstract}
Different types of cucumbers culture, respectively organic system and the system of chemical and organic fertilization can influence vegetable quality. The present study was carried out in a solarium on a farm, in six experimental variants, three replications. Three variants for fertilization systems with two cucumbers cultivars were used. The biological material used in the experiments consisted of the cultivars 'Triumf' F1 and 'Mirabelle' F1. Fertilization systems used were organic with manure, classic with chemical fertilizers and soluble complex fertilizers with fertigation. In the present research agrochemical and biochemical characteristics were analysed and also weight of fruits and yield on plants and $\mathrm{kg} / \mathrm{m}^{2}$ were measured. Agrochemical characteristics were: contents of nitrates, phosphorus and potassium from cucumbers and the biochemical characteristics measured were: acidity, soluble carbohydrates, vitamin $\mathrm{C}$ and dry matter. The results showed that the fertilization with soluble complex fertilizers in addition with fertigation assured the entire necessary for the growth and fructification of cucumbers. The presence of chemical fertilizers do not influence in a negative way the nitrates, phosphorus and potassium content and the quality of consumption of cucumbers was assured. Regarding the cultivars the best yield and quality results were obtained to 'Mirabelle' F1.
\end{abstract}

Keywords: biochemical characteristics, cultivars, organic and chemical fertilizers

\section{Introduction}

Growing cucumbers in Romania is, in most cases, based on the organic system and the system of chemical and organic fertilization. These types of culture can influence vegetable quality owing to increased photosynthesis. Cucumber crop occupies the land for four months, the mandatory technology should support vegetative growth and build upon the fertilization phases. Fertilization based on soil cucumber crops is limited to a moderate amount of fertilizer since root sensitivity does not support high concentrations of minerals with chloral and sulphates in the soil (El-Dakish, 2004). Traditional phase fertilization is also relatively difficult due to their difficult insert into the soil from the technological point of view and the superficial striking roots of the cucumbers plant. Also, phase fertilization in leaps is no solution for the growth and fruition of the soil-grown cucumbers (El-Dakish, 2004). The occurrence of soluble complexes fertilizers containing a complete range of macro and micro elements on the market simplifies the applied mode and efficiency of phase fertilization effect in the cucumber crop grown in the solariums (Massantini, 1988).

Drip fertilization is applied on the vigorous plants every day by using equal norms with daily consumption (El-Dakish, 2004). Thus, soil humidity can be maintained at constant values as the fertilizers necessary for phase fertilization allow plant supply with nutritive elements in agreement with consumption. Thus, the positive effects of irrigation and phase fertilization applied in culture are combined with the aim of achieving high yield and quality (Mao et al., 2003).

An experiment was conducted to study the different effects of special compound fertilizer presented in Tab.1, pure chemical fertilizer and pure organic fertilizer on growth, yield and quality of cucumber in soil greenhouse (Fang, 2005). Compared with the effect of pure chemical fertilizer or organic fertilizer could greatly improve the cucumber's quality and determined lower content of $\mathrm{N}-\mathrm{NO}_{3}$ :

The influence of fertilization system on the quality of vegetables was study by a lot of researchers around the world: Granges et al. (2000) determined the dry matter contents, carotenoids and acidity characteristics of different vegetables in different fertilizer conditions, Noguera et al. (1988) determined dry matter contents, Massantini (1962) determined the sugar content and Thybo et al. (2005) also determined the acidity contents of vegetables in different conditions of culture in greenhouse. These characteristics were determined at the finish of vegetable culture of cucumbers at different cultivars and phase of maturity (Noguera, 2005; Parks, 2004). 
The aim of the research was to establish the agrochemical and biochemical characteristics of cucumbers grown on two fertilization systems respectively organic fertilization and chemical and organic fertilization.

\section{Materials and methods}

The experiment was carried out in a private solarium on a farm in southern Romania Barcanesti village, in six variants and three replicates, in lots of $5 \mathrm{~m}^{2} /$ replicate. The experiment was protected by protection strips, to avoid the influence of different system fertilization applied according to the experimental technique.

The biological material used in experience consisted of cucumber cultivars 'Triumf'F1 and 'Mirabelle' F1.

'Triumf' F1 had early growing period of 75 days used for cultivation in protected and open field. Chornichon are cylindrical fruit with brown hairs, the pulp is firm, with a pleasant taste without bitterness, with specific flavor. Production capacity: $45 \mathrm{t} / \mathrm{ha}$, good resistance to pathogen attack, perfectly adapted to the agro-soil of the area.

'Mirabelle' F1 had a very early growing and shows a high efficiency throughout the production cycle. Is a flexible hybrid with open foliage, which enables the work in solar or field. Excellent uniformity, thin cylindrical fruits and dark green color, fruits do not have a bitter taste and length thickness ratio is 3.3:1.

The soil from solarium was prepared for the cucumber crop by adding in spring (20 February) of $20 \mathrm{t} /$ ha manure in variants V11 and V12, while $250 \mathrm{~kg} / \mathrm{ha}$ complex fertilizer with the formula 15:15:15 was applied in variants V21 and V22. After transplantation, soluble fertilizers were applied by irrigation to each replicate (amounts are presented in Tab. 1).

The adding of complex fertilizers in variants V31 and V32 were made at the three phases respectively: immediately near transplanting for one week time was applied fertilizer I with formula $15 \mathrm{~N} ; 30 \mathrm{P}_{2} \mathrm{O}_{5} ; 15 \mathrm{~K}_{2} \mathrm{O}$, than was applied fertilizer II with formula $14 \mathrm{~N}_{1} ; 1 \mathrm{P}_{2} \mathrm{O}_{5} ; 25 \mathrm{~K}_{2} \mathrm{O}$ till flowering and after that was applied fertilizer III $24 \mathrm{~N}$; $8 \mathrm{P}_{2} \mathrm{O}_{5} ; 16 \mathrm{~K}_{2} \mathrm{O}$ which favoured fruition till the harvest. In this case fertilizers were added with daily watering.

Watering was uniform, and was performed by using the irrigation installation of the solarium.
Watering was done during the vegetation season 20 March-5 June. The cucumbers were harvested from the variants and replicates, and measurements were performed on the yield medium weight and the agrochemical (nitrates, phosphorus and potassium) and biochemical (soluble carbohydrates, acidity, vitamin $\mathrm{C}$ and dry matter) quality characteristics. The cucumber fruit were numbered and weighted in order to calculate the average yield and weight.

The agrochemical characteristics analysed were nitrates, phosphorus and potassium soluble forms obtained from the $\mathrm{CH}_{3} \mathrm{COOH}$ extraction, ratio 1:20 and dosing as follows: for nitrates was used the colorimetric method at $\lambda=420 \mathrm{~nm}$, with fenoldisulfonic acid reactive in basic medium, for phosphorus was used also colorimetric method at $\lambda=720 \mathrm{~nm}$, with Duval reactive and ascorbic acid and the phlamphotometric method for potassium (Davidescu et al., 1972).

Biochemical characteristics were soluble carbohydrates measured according to the Abbe method, acidity in extraction with water and volumetric method for dosing with $\mathrm{NaOH}$ and vitamin $\mathrm{C}$ extraction with $\mathrm{HCl}$, and the iodometric dosing method (Davidescu et al., 1963).

Finally statistical interpretation of the results was performed using variance analysis of production, Fisher's exact test.

\section{Results and discussion}

Nitrates are the compounds affecting the consumers' health if the Maximum Admitted Content assured through the Governmental Ordinance No.1 / 2002 by the Ministry of Health could determine the unused of vegetables for trading. In the case of growing cucumbers in solarium, Maximum Admitted Content is 400 ppm N-NO3. In our experiment, the analysis of the nitrates showed that the chemical fertilizer determined an increased content in the traditionally fertilized variants, as well as in the variants based on the soluble chemical fertilizers. The average values in the case of traditional fertilization varied between 233 ppm N-NO3 in the 'Mirabelle' F1 cultivar and 252 ppm N-NO3 in the 'Triumf' F1 cultivar whereas in the case of fertigation they varied between 153 ppm N-NO3 in 'Triumf' F1 and 114 ppm N-NO3 in 'Mirabelle' F1

Tab 1. Experimental variants in cornichon cucumber crop

\begin{tabular}{|c|c|c|c|}
\hline Var. no. & Fertilization & Cultivars & Fertilization scheme \\
\hline V11 & \multirow{2}{*}{ Organic } & 'Triumf' F1 & \multirow{2}{*}{$20 \mathrm{t} /$ ha Manure } \\
\hline V12 & & 'Mirabelle' $\mathrm{F}_{1}$ & \\
\hline V21 & \multirow[b]{2}{*}{ Classic } & 'Triumf' $\mathrm{F}_{1}$ & $-250 \mathrm{~kg} / \mathrm{ha}$ complex fertilizers $15-15-15$ applied at the beginning of culture \\
\hline V22 & & 'Mirabelle' $F_{1}$ & $\begin{array}{c}\text {-two phasial fertilizations, } 100 \mathrm{~kg} / \mathrm{ha} \text { of the same fertilizers, two } \\
\text { times, at three and six weeks after transplantation }\end{array}$ \\
\hline V31 & \multirow{2}{*}{$\begin{array}{l}\text { Soluble } \\
\text { Complex } \\
\text { fertilizers }\end{array}$} & 'Triumf' $\mathrm{F}_{1}$ & \multirow{2}{*}{$\begin{array}{l}\text { I.-15 N; } 30 \mathrm{P}_{2} \mathrm{O}_{5} ; 15 \mathrm{~K}_{2} \mathrm{O} \text {-which favoured the transplanting rooting immediately after transplantation } \\
\text { II.-14N;11 } \mathrm{P}_{2} \mathrm{O}_{5} ; 25 \mathrm{~K}_{2} \mathrm{O} \text {-favoured vegetative growth after transplantation; } \\
\text { III.-24N; } ; 8 \mathrm{P}_{2} \mathrm{O}_{5} ; 16 \mathrm{~K}, \mathrm{O} \text {-favoured fruition of vegetable crops. }\end{array}$} \\
\hline V32 & & 'Mirabelle' $F_{1}$ & \\
\hline
\end{tabular}


Tab 2. The agrochemical characteristics of cucumbers at harvest time

\begin{tabular}{|c|c|c|c|c|c|c|c|c|c|c|c|}
\hline \multirow{3}{*}{ Var. } & \multirow{3}{*}{ Fertilization } & \multirow{3}{*}{ Cultivars } & \multicolumn{9}{|c|}{ Content. ppm } \\
\hline & & & \multicolumn{3}{|c|}{ N-NO3 } & \multicolumn{3}{|c|}{ P-PO4 } & \multicolumn{3}{|c|}{$\mathrm{K}$} \\
\hline & & & $\operatorname{Min} \div \operatorname{Max}$ & Average & $\%$ & $\operatorname{Min} \div \operatorname{Max}$ & Average & $\%$ & Min. $\div$ Max & Average & $\%$ \\
\hline $\mathrm{V}_{11}$ Control 1 & \multirow{2}{*}{ Organic } & 'Triumf' $F_{1}$ & $75 \div 102$ & 87 & 100.00 & $146.23 \div 168.12$ & 154.53 & 100.00 & $888 \div 932$ & 920 & 100.00 \\
\hline $\mathrm{V}_{12}$ Control 2 & & 'Mirabelle' $F_{1}$ & $88 \div 110$ & 95 & 100.00 & $114.56 \div 136.15$ & 124.56 & 100.00 & $995 \div 1120$ & 1060 & 100.00 \\
\hline $\mathrm{V}_{21}$ & \multirow{2}{*}{ Classic } & 'Triumf' $\mathrm{F}_{1}$ & $198 \div 265$ & 252 & 289.65 & $162.12 \div 185.54$ & 173.62 & 112.53 & $2245 \div 2580$ & 2400 & 260.86 \\
\hline $\mathrm{V}_{22}$ & & 'Mirabelle' $F_{1}$ & $185 \div 245$ & 233 & 245.26 & $198.23 \div 224.20$ & 214.52 & 172.22 & $1996 \div 2170$ & 2060 & 194.33 \\
\hline $\mathrm{V}_{31}$ & \multirow{2}{*}{$\begin{array}{l}\text { Soluble Complex fertilizers } \\
\text { (Fertirrigation) }\end{array}$} & 'Triumf' $F_{1}$ & $140 \div 168$ & 153 & 175.86 & $165.12 \div 189.23$ & 173.00 & 112.17 & $2010 \div 2156$ & 2100 & 228.26 \\
\hline $\mathrm{V}_{32}$ & & 'Mirabelle' $F_{1}$ & $101 \div 119$ & 114 & 120.00 & $159.56 \div 225.86$ & 200.13 & 160.67 & $1758 \div 1920$ & 1850 & 174.52 \\
\hline
\end{tabular}

Tab 3. The biochemical characteristics of cucumbers at harvest time

\begin{tabular}{|c|c|c|c|c|c|c|c|c|c|c|c|c|c|c|}
\hline \multirow[t]{2}{*}{ Var } & \multirow[t]{2}{*}{ Fertilization } & \multirow[t]{2}{*}{ Cultivars } & \multicolumn{3}{|c|}{ Soluble carbohydrates (\%) } & \multicolumn{3}{|c|}{ Acidity \% } & \multicolumn{3}{|c|}{$\begin{array}{l}\text { Vitamin C, mg ascorbic } \\
\text { acid /100g p.p. }\end{array}$} & \multicolumn{3}{|c|}{ Dry matter, \% } \\
\hline & & & $\operatorname{Min} \div \operatorname{Max}$ & Average & $\%$ & $\operatorname{Min} \div \operatorname{Max}$ & Average & $\%$ & $\operatorname{Min} \div \operatorname{Max}$ & Average & $\%$ & $\operatorname{Min} \div \operatorname{Max}$ & Average & $\%$ \\
\hline $\mathrm{V}_{11}$ & \multirow{2}{*}{ Organic } & 'Triumf' $F_{1}$ & $2.9 \div 3.06$ & 3.05 & 100.00 & $0.27 \div 0.32$ & 0.30 & 100.00 & $18.55 \div 18.85$ & 18.65 & 100.00 & $3.08 \div 3.14$ & 3.12 & 100.00 \\
\hline $\mathrm{V}_{12}$ & & 'Mirabelle' $F_{1}$ & $2.89 \div 3.1$ & 3.02 & 100.00 & $0.25 \div 0.29$ & 0.28 & 100.00 & $18.70 \div 19.15$ & 18.95 & 100.00 & $3.16 \div 3.28$ & 3.25 & 100.00 \\
\hline $\mathrm{V}_{21}$ & \multirow{2}{*}{ Classic } & 'Triumf' $\mathrm{F}_{1}$ & $2.68 \div 2.86$ & 2.78 & 91.14 & $0.35 \div 0.42$ & 0.39 & 130.00 & $18.07 \div 18.20$ & 18.15 & 97.32 & $2.98 \div 3.04$ & 3.01 & 96.47 \\
\hline $\mathrm{V}_{22}$ & & 'Mirabelle' $F_{1}$ & $2.75 \div 2.88$ & 2.85 & 94.37 & $0.38 \div 0.41$ & 0.40 & 142.85 & $18.12 \div 18.45$ & 18.35 & 184.69 & $2.92 \div 3.02$ & 2.98 & 91.69 \\
\hline $\mathrm{V}_{31}$ & \multirow{2}{*}{$\begin{array}{c}\text { Soluble Complex } \\
\text { fertilizers (Fertirrigation) }\end{array}$} & 'Triumf' $\mathrm{F}_{1}$ & $2.36 \div 2.52$ & 2.48 & 81.31 & $0.33 \div 0.37$ & 0.35 & 116.66 & $19.55 \div 19.86$ & 19.70 & 105.63 & $2.85 \div 2.92$ & 2.85 & 91.34 \\
\hline$V_{32}^{11}$ & & 'Mirabelle' $F_{1}$ & $2.26 \div 2.32$ & 2.29 & 75.82 & $0.29 \div 0.32$ & 0.31 & 110.71 & $19.12 \div 19.35$ & 19.26 & 101.63 & $2.70 \div 2.80$ & 2.74 & 84.30 \\
\hline
\end{tabular}


Tab.4. Results regarding the yield and average weight of fruit, average per variant

\begin{tabular}{|c|c|c|c|c|c|c|}
\hline \multirow{2}{*}{ Var. } & \multirow{2}{*}{$\begin{array}{c}\text { Type of } \\
\text { fertilization }\end{array}$} & \multirow{2}{*}{ Cultivars } & \multicolumn{3}{|c|}{ Yield } & \multirow{2}{*}{$\begin{array}{l}\text { Medium weight } \\
\text { of fruit ( } \mathrm{g} / \text { fruit) }\end{array}$} \\
\hline & & & $\mathrm{kg} /$ plant & $\mathrm{kg} / \mathrm{m}^{2}$ & Significance & \\
\hline $\mathrm{V} 1-\mathrm{Ct}$ & \multirow{2}{*}{ Organic fertilization } & 'Triumf' $F_{1}$ & 1.021 & 2.226 & - & 25.13 \\
\hline $\mathrm{V} 2-\mathrm{Ct}$ & & 'Mirabelle' $F_{1}$ & 1.084 & 2.384 & - & 25.46 \\
\hline V3 & \multirow{2}{*}{ Classic } & 'Triumf' $F_{1}$ & 2.150 & 4.730 & ${ }^{* * *}$ & 52.45 \\
\hline V4 & & 'Mirabelle' $F_{1}$ & 2.408 & 5.925 & *** & 50.16 \\
\hline V5 & \multirow{2}{*}{$\begin{array}{c}\text { Soluble Complex } \\
\text { fertilizers }\end{array}$} & 'Triumf' $F_{1}$ & 3.094 & 6.808 & $* * *$ & 54.37 \\
\hline \multirow[t]{4}{*}{ V6 } & & 'Mirabelle' $F_{1}$ & 4.136 & 9.100 & ${ }^{* * *}$ & 57.13 \\
\hline & LSD $5 \%=$ & & & 0.347 & & \\
\hline & LSD $1 \%=$ & & & 0.665 & & \\
\hline & LSD $0.1 \%=$ & & & 1.174 & & \\
\hline
\end{tabular}

(Tab. 2). Comparing the nitrate values resulted from the cucumber crop with the Maximum Admitted Content, it can be noticed that all experimental variants had low values of nitrates which assured a good quality for cucumber consumption (Ciofu, 2003; Gul, 1992, 1994).

Concerning the content in phosphorus, it varied from 124.56 ppm P in 'Mirabelle' F1 based with organic fertilizers to $214.52 \mathrm{ppm} P$ in 'Mirabelle' F1 with classic fertilization. These values assured a good content in phosphorus for cucumbers, phosphorus is the macroelement which determined the quality of vegetable for consumption (Kader, 2001). Regarding potassium, it varied from 920 ppm K in 'Triumf' F1cultivar at variants V11 and V12 with organic fertilization to $2100 \mathrm{ppm} \mathrm{K}$ in 'Triumf' $\mathrm{F} 1$ at variants V31 and V32 based on soluble complex fertilizers.

Biochemical characteristics assured the savoury of cucumbers fruits. Soluble carbohydrates varied from $2.29 \%$ to $3.05 \%$ (Tab. 3). In the case of organic fertilization, carbohydrates were accumulated in high quantities, i.e. between $3.02 \%$ and $3.05 \%$; compared with the cucumbers cultivated under classic fertilization conditions, values between $2.78 \%$ and $2.85 \%$ were obtained from soluble complex fertilization respectively variants V31 and V32.

In our experiment, acidity varied from $0.28 \%$ to $0.40 \%$. The highest values were achieved under classic fertilization conditions, i.e. $0.39 \%$ and $0.40 \%$ while the lowest were obtained from organic fertilization, i.e. $0.28 \%$ and $0.30 \%$.The content in vitamin $\mathrm{C}$ accumulated in amounts varied from $8.15 \mathrm{mg} / 100 \mathrm{~g}$ to $19.80 \mathrm{mg} / 100 \mathrm{~g}$. In the case of Soluble Chemical fertilizer, the compound stimulated accumulation between $19.26 \mathrm{mg} / 100 \mathrm{~g}$ and $19.70 \mathrm{mg} / 100$ $\mathrm{g}$ while the lowest values were achieved by classic fertilization, from $18.15 \mathrm{mg} / 100 \mathrm{~g}$ to $18.35 \mathrm{mg} / 100 \mathrm{~g}$.

Dry matter accumulated in the experimental variants ranged between $2.74 \%$ and $3.25 \%$, the higher accumulation being recorded as organic fertilization.

Cucumber production varied depending on fertilization and cultivar (Tab. 4).

The organic fertilization resulted in the lowest production of any particular cultivar varied from $1.021 \mathrm{~kg} / \mathrm{plant}$ to $1.084 \mathrm{~kg} /$ plant. The highest yields were obtained from fertigation with Soluble Chemical fertilizers, where the output varied between $4.136 \mathrm{~kg} /$ plant in 'Mirabelle' F1 and $3.094 \mathrm{~kg} /$ plant in 'Triumf' F1.

Regarding the cultivars used in the experiment, 'Mirabelle' F1 recorded a better development, which resulted in differences in achieving a high yield. The highest yield was obtained in the variants based on fertigation with Soluble Complex fertilizers, where 'Mirabelle' F1 determined a yield of $4.136 \mathrm{~kg} /$ plant. The average weight of the cucumber fruit also varied depending not only fertilization but also on the cultivation and use. The highest average weight of fruit was obtained in 'Mirabelle' F1, $57.13 \mathrm{~g}$, under conditions of fertigation with Soluble Complex fertilizers. The statistical interpretation of the yield (Tab. 4) show that the results obtained from classic fertilization and Soluble Complex fertilizers were statistically significant compared with those obtained from organic fertilization.

Fertilization with $20 \mathrm{t} /$ ha manure determined cucumbers with medium weight ranging between $25.13 \mathrm{~g}$ and $25.46 \mathrm{~g} /$ fruit and yields between $2.226 \mathrm{~kg} / \mathrm{m}^{2}$ and 2,384 $\mathrm{kg} / \mathrm{m}^{2}$, as low production because plant nutrition was not properly secured with $\mathrm{N}, \mathrm{P}, \mathrm{K}$, amounts made available organic fertilizer is low (Succop, 2004).

When using chemical fertilizers (classic fertilization) recorded increases of fruit weight of 2.08 times to 'Triumf' F1 and 1.97 times at cultivar 'Mirabelle' F1 and production reaching $2.150 \mathrm{~kg} / \mathrm{m}^{2}$ at 'Triumf' $\mathrm{F} 1$ and $2.408 \mathrm{~kg} / \mathrm{m}^{2}$ at 'Mirabelle' F1. Observed increases are achieved due to ensure the necessary nutrients both at the beginning of the growing season and during fruiting (Baevre, 1985).

In the case of fertigation when using soluble complex fertilizers is different from the other two variants of fertilization as fertilizers used were made available to plants as their nutritional requirements used with watering. Fertilizers in this case are completely soluble and because of spaghetti use are in the vicinity of plant roots. Nutrition is how to ensure continuous flow (Armengol and Serrano, 1988; Gruda, 2005).

Experience has shown that mineral nutrition required parameters must be ensured continuous plant which was best achieved by fertigation with soluble fertilizer complex. 
230

\section{Conclusions}

Using three different fertilization results showed that to obtain high quantity production in greenhouses is necessary to apply fertilizers. Between the two types of fertilizers used in the classical and variant soluble complex fertilizers is preferred second and fertigation needed. In terms of quality all fertilization variants have led to the accumulation of large quantities of nitrates, phosphates and potassium in the normal consumer does not affect the quality of cucumbers. Biochemical characteristics (acidity, soluble carbohydrates and vitamin C) are within the presented literature (Gherghi, 2001).

\section{References}

Armengol F, Serrano A (1988). Growth and development, water absorption and mineral composition of tomato plants grown with the nutrient film technique in the east Mediterranean coast region of Spain. Acta Hort 221:203-211.

Baevre OA (1985). A comparison of the fruit quality of tomatoes grown in soil and in a nutrient solution (NFT). Scientific Reports of the Agricultural University of Norway 64:110.

Ciofu R, Stan N, Popescu V, Chilom P, Apahidean S, Horgos A, Berar V, Lauer KF, Atanasiu N (2003). Tratat de legumicultura. Ed. CERES, Bucuresti. Romania, 1130 p.

Davidescu D, Davidescu V (1972). Testarea starii de fertilitate prin planta si sol. Ed. Academiei RSR 115-132 p.

Davidescu D, Ionescu M, Ivanescu M, Slusanschi H, Pavlovschi G(1963). Metode de analiza chimice chimice si fizice folosite in agricultura. Ed. Academiei RSR 225-290 p.

El-Dakish MH (2004). Growth development and yield of cucumber as affected by irrigation frequency and mineral fertilization versus organic manure. Assiut Univ Bull Environ Res 7(2):65-76.

Fang Y (2005). Study on effects of special compound fertilizer on yield and quality of cucumber in greenhouse. Hubei Agricultural Sciences 2005-03, CNKI: SUN:HBNY.O.2005-03 032.

Gherghi A, Burzo I, Bibicu M, Margineanu L, Badulescu L (2001). Biochimia si fiziologia legumelor si fructelor. Ed.Academiei Romane.

Granges A, Azodanlou R, Cuovreur F, Reuter E (2000). Méthode de culture et qualité organoleptique de tomates cultivées en serre et en plein champ. Revue Suisse Vitic Arboric Hor- tic 32:175-180

Gruda N(2005). Impact of environmental factors on product quality of greenhouse vegetables for fresh consumption. Critical Review in Plant Science 24, 227-247.

Gül A, Sevgican A ( 1992). Effect of growing media on glasshouse tomato quality. Acta Hort 303:145-150.

Gü, A, Sevgican A (1994). Suitability of various soilless media for longterm tomato growing. Acta Hort 366:37-44.

Kader AA (2001). Quality assurance of harvested horticultural perishables. Acta Hort 553:51-55.

Mao X, Liu M, Wang X, Liu C, Hou Z, Shi J (2003). Effects of deficit irrigation on yield and water use of greenhouse grown cucumber in the North China Plain. Agric Water Manage 61:219-228.

Massantini F (1962). Rilievi sulle caratteristiche qualitative di frutti di pomodoro provenienti da colrivazioni normali e da coltivazioni di serra ordinaria e idroponica. Riv Ortoflorofruttic Ital 6:410-421.

Massantini F, Favilli R, Magnani G, Oggiano N (1988). Soilless culture-biotechnology for high quality vegetables. Soilless Culture 4:27-40.

Noguera V, Abad M, Pastor JJ, Garcia-Codoñer AC, Mora J, Thybo AK, Bechmann IE, Brandt K (2005). Integration of sensory and objective measurements of tomato quality: quantitative assessment of the effect of harvest date as compared with growth medium (soil versus rockwool), electrical conductivity, variety and maturity. J Sci Food and Agri 85:2289-2296.

Parks S, Newman S, Golding J (2004). Substrates effects on greenhouse cucumber growth and fruit quality in Australia. Acta Hort 648:129-133.

Succop CE, Newman SE (2004). Organic fertilization of fresh market sweet basil in a greenhouse. HortTechnology 14:235239.

Thybo AK, Bechmann IE, Brandt K (2005). Integration of sensory and objective measurements of tomato quality: quantitative assessment of the effect of harvest date as compared with growth medium (soil versus rockwool), electrical conductivity, variety and maturity. J Sci Food and Agri 85:22892296.

*** Governmental Ordinance No.1 / 2002 by the Ministry of Health. 